\title{
PENANGANAN LUKA TERBUKA PADA AXILLA KUCING DOMESTIK METODE SKIN FLAPPING ROTATION FLAPS
}

\author{
Liza Sadda Cakrawati $^{*}$, Ajeng Aeka Nurmaningdyah ${ }^{1}$, Galuh Purnawati ${ }^{1}$, Hasan Ashari ${ }^{1}$, Kirana \\ Sita Pinasthika ${ }^{1}$ \\ ${ }^{1}$ Fakultas Kedokteran Hewan, Universitas Brawijaya Malang \\ *Email: lizasadda@student.ub.ac.id
}

\begin{abstract}
Injuries on the axilla of a cat are often the result of pinching the skin by necklaces, accidents, and other traumatic events. Entanglement of objects in the cat's axillar will cause deep wounds that can lead to open wounds. Wounds with open conditions can allow pathogens to enter so that they can cause infection and require proper handling. This journal aims to determine the diagnosis and treatment methods for open wounds in the axilla section of cats at the Faculty of Veterinary Medicine, Brawijaya University. The Domestic Short Hair (DSH) cat is male, age unknown, and body weight $4.25 \mathrm{~kg}$ has an open wound on the axilla of the cranial dexter limb. The wound was $5 \mathrm{~cm}$ in diameter. Laboratorium examinations with a complete blood count and a tape smear. The surgery performed was the skin flapping rotation flaps method. Post operative care includes wound cleaning, ceftriaxone antibiotics, and antiinflammatory ketoprofen. The method of handling in this case can be concluded that skin flapping can be used in the treatment of open wounds in cats. Wound healing can be influenced by extrinsic and intrinsic factors. How to handle this, it can be concluded that skin flapping can be used in the treatment of open wounds in cats.
\end{abstract}

Keywords: axilla, cat, open wound, rotation flaps, skin flapping

\section{PENDAHULUAN}

Kulit merupakan organ tubuh terbesar yang memiliki banyak fungsi penting, termasuk perlindungan terhadap bahaya fisik, kimia, dan biologis eksternal, serta sebagai pencegahan kehilangan air berlebih dari tubuh dan peran dalam termoregulasi (Kanitakis, 2002). Kulit bersifat sebagai barier yang penting untuk mencegah mikroorganisme dan agen perusak potensial lain masuk ke dalam jaringan yang lebih dalam. Ketika kulit yang berfungsi sebagai barier rusak atau hilang sebagian maka agen patogen dan mikroorganisme dapat menginfeksi dengan mudah dan masuk kedalam tubuh lebih cepat dan akan merangsang respon imun (Baroni et al, 2012).

Luka pada axilla kucing sering disebabkan karena terjepitnya kulit oleh kalung, kecelakaan, dan peristiwa traumatis lainnya. Jeratan benda pada axillar kucing akan menimbulkan luka yang dalam sehingga dapat menjadi luka terbuka. Luka dengan kondisi yang terbuka dapat menyebabkan patogen masuk sehingga dapat menyebabkan infeksi. Luka yang cukup luas pada axilla perlu dilakukan tindakan bedah dengan metode skin flap. Skin flap merupakan salah satu teknik penutupan luka yang berukuran besar. Kelonggaran kulit sekitar luka dapat dijadikan dasar untuk pemilihan jenis skin flap, untuk penanganan area luka pada ekstremitas ditangani dengan distant flap (Erwin dkk., 2020). Keberhasilan teknik skin flap ditentukan oleh vaskularisasi yang sehat di daerah penempelan (dasar luka). Kulit yang didonorkan juga harus memiliki vaskularisasi, laju cairan di dalamnya berfungsi dengan baik, serta penempelan harus stabil dan tidak terjadi banyak pergerakan. 


\section{RIWAYAT KASUS}

Kucing yang mengalami luka terbuka pada area axilla merupakan kucing spesies domestic short hair berwarna orange putih, berjenis kelamin jantan, berumur 5 tahun, dan memiliki berat badan $4,25 \mathrm{~kg}$. Terdapat luka terbuka pada bagian axilla ekstremitas cranial dexter. Luka terbuka tersebut sudah berlangsung selama 2 tahun. Berdasarkan informasi dari pemilik, sudah pernah dilakukan terapi pengobatan namun tidak kunjung sembuh. Kondisi kucing tersebut aktif. Kucing belum disteril, belum divaksin dan belum diberikan obat cacing maupun obat anti ektoparasit.

\section{DISKUSI}

Kondisi dari kucing kasus tersebut yaitu: frekuensi denyut jantung 104 kali/menit, laju respirasi $36 \mathrm{kali} / \mathrm{menit}$, Capillary Refill Time (CRT) 2 detik, suhu tubuh $38,6{ }^{\circ} \mathrm{C}$, Body Condition Score (BCS) $3 / 5$, turgor kulit 2 detik. Pada axilla ekstremitas cranial dexter terdapat luka terbuka berbentuk bulat, berwarna merah dan kondisi luka tersebut lembab (Gambar 1). Rambut di area sekitar luka tipis dan kotor serta luka tersebut sedikit berbau.

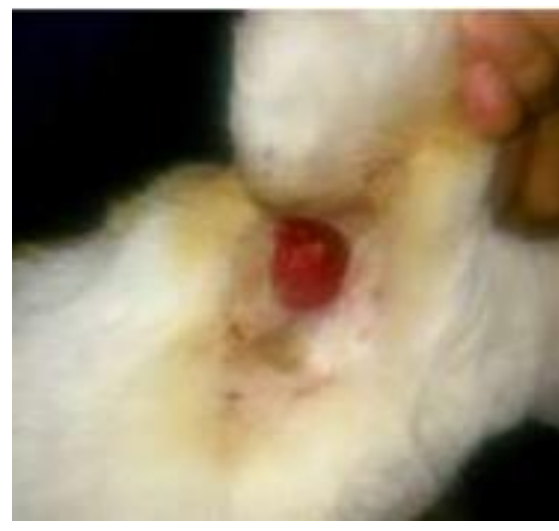

Gambar 1. Luka terbuka pada daerah axilla ekstremitas cranial dexter

Pemeriksaan penunjang yang dilakukan yaitu meliputi pemeriksaan darah lengkap dan tape smear kulit pada luka. Hasil pemeriksaan darah menunjukkan leukositosis, granulositosis, peningkatan hemoglobin, MCV (Mean Corpuscular
Volume), hematokrit dan penurunan limfosit. Hasil pemeriksaan darah lengkap dapat dilihat pada Tabel 1.

Tabel 1. Hasil Pemeriksaan Darah Lengkap

\begin{tabular}{ccc}
\hline Keterangan & Hasil & Nilai Normal \\
\hline WBC $(\boldsymbol{\mu L})$ & $30,1 \times 10^{3}$ & $6-19,5$ \\
\hline LYM $(\boldsymbol{\mu L})$ & $3 \times 10^{3}$ & $0,8-7$ \\
\hline GRAN $(\boldsymbol{\mu L})$ & $26 \times 10^{3}$ & $2,1-15$ \\
\hline RBC $(\boldsymbol{\mu L})$ & $9,58 \times 10^{6}$ & $4,6-10$ \\
\hline HGB $(\mathbf{g} / \mathbf{d L})$ & 16,1 & $9,3-15,3$ \\
MCHC & 30,8 & $30-38$ \\
$\mathbf{( g / d L )}$ & 16,8 & $13-21$ \\
MCH $(\mathbf{p g})$ & 54,5 & $39-52$ \\
MCV $(\mathbf{f L})$ & 52,2 & $28-49$ \\
HCT $(\boldsymbol{\%})$ & $185 \times 10^{3}$ & $100-514$ \\
\hline PLT $(\boldsymbol{\mu L})$ & \\
\hline
\end{tabular}

Hasil pemeriksaan tape smear pada luka terbuka menunjukkan adanya sel leukosit dan sel darah merah yang dapat dilihat pada Gambar 2.

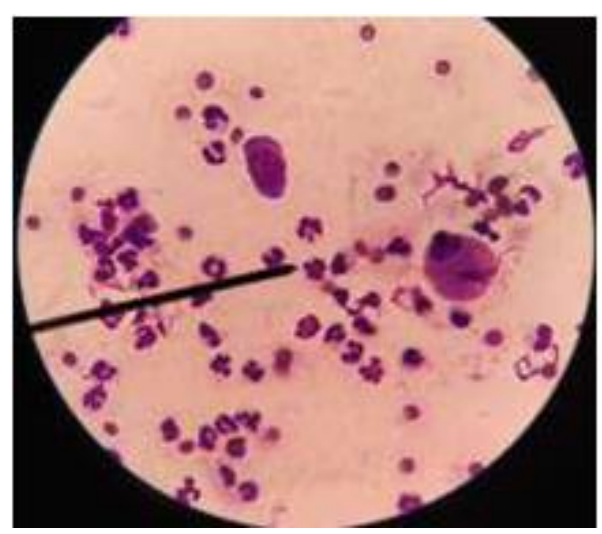

Gambar 2. Pemeriksaan tape smear pada luka terbuka ditemukan banyak sel leukosit dan sel darah merah

Tindakan bedah perlu dilakukan untuk menutup luka terbuka dengan metode skin flap. Sebelum dilakukan tindakan bedah, kucing tersebut diberikan premedikasi menggunakan atropine sulfat $0,04 \mathrm{mg} / \mathrm{kg} \mathrm{BB}$ secara subkutan. Kemudian setelah 15 menit 
dilakukan pemberian anastesi menggunakan kombinasi xylazine $1 \mathrm{mg} / \mathrm{kg} \mathrm{BB}$ dan ketamine $\quad 10 \quad \mathrm{mg} / \mathrm{kg} \quad \mathrm{BB}$ secara intramuskular. Selanjutnya, ditunggu kucing tersebut sampai hilang kesadaran. Pertama dilakukan pencukuran rambut pada daerah kulit yang akan dilakukan operasi yang meliputi daerah thorax, abdomen dan axilla. Kemudian diukur dan digambar pada area kulit yang menjadi donor untuk luka tersebut. Area yang akan dioperasi dibersihkan menggunakan iodin. Kemudian, incisi pola yang telah digambar. Kulit donor diposisikan ke area luka terbuka dan dijahit menggunakan benang vicryl 2.0 dengan pola jahitan simple interrupted. Disatukan kulit bagian tengah yaitu bagian abdomen yang menjadi donor dengan jahitan simple interupted. Prosedur operasi skin flap dapat dilihat pada Gambar 3.
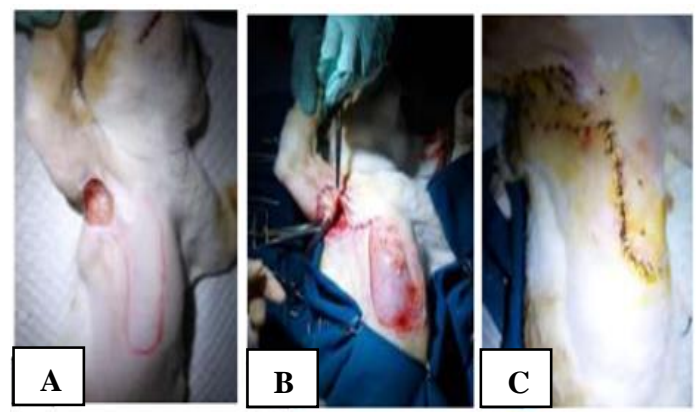

Gambar 3. Prosedur Operasi Skin Flap. (A) Penggambaran pada area kulit donor. (B) Proses rotasi dari kulit donor dan penutupan luka. (C) Penutupan luka secara keseluruhan menggunakan simple interrupted

Terapi pasca operasi yang dilakukan yaitu dengan pemberian antibiotik ceftriaxone rute IM dengan dosis $25 \mathrm{mg} / \mathrm{kg}$ BB sebanyak 2 kali sehari selama lima hari untuk mencegah infeksi serta pemberian ketoprofen dosis $1 \mathrm{mg} / \mathrm{kg}$ BB satu hari sekali secara PO selama 5 hari sebagai analgesik dan antiinflamasi. Perawatan pascaoperasi terhadap luka yaitu dibersihkan setiap dua kali sehari dan diberikan terhadap luka yaitu dengan pemberian antibiotik gentamicin berupa salep dan dibalut dengan kasa steril. Berikut merupakan kondisi pasca operasi selama 7 hari (Gambar 4).

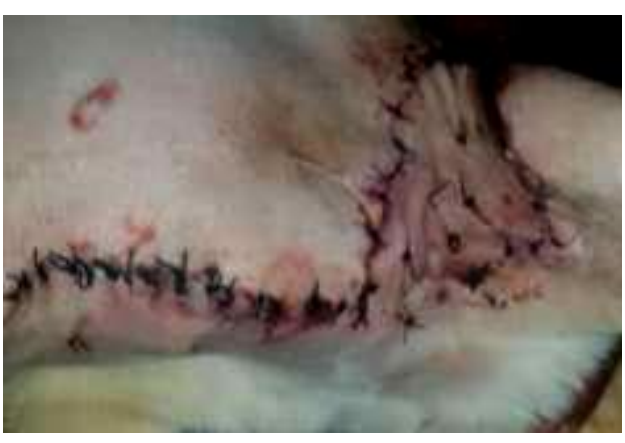

Gambar 4. Kondisi luka pasca operasi 7 hari

Skin flapping merupakan suatu teknik rekonstruksi yang digunakan ketika seekor hewan memiliki luka terbuka yang luas. Penanganan kasus ini membutuhkan suatu flap untuk menutup luka. Penggunaan skin flapping dilakukan untuk menghindari terjadinya trauma sekunder serta mengembalikan kondisi fisiologis normal kulit (Tsuroyya dan Adji, 2018). Pembebasan kulit untuk skin flap meliputi beberapa lapisan jaringan seperti dermis, epidermis, jaringan subkutan, fasciocutaneous, myocutaneous, osseocutaneous, kadang-kadang jaringan otot, jaringan sensorik dan mungkin jaringan adiposa, yang didasarkan pada jaringan mikrovaskular. Klasifikasi skin flap dibagi berdasarkan lokasi donor, desain geometri dan komposisi dari jaringan vaskular.

Kulit yang digunakan sebagai donor berasal dari bagian abdomen dengan arteri disekitar axila sebagai sumber vaskularisasi. Kasus tersebut menunjukkan bahwa skin flap dapat dilakukan pada kucing, terutama pada beberapa daerah yang kurang vaskularisasi dan cadangan kulit. Penutupan luka dengan skin flap juga harus memperhatikan kelonggaran kulit untuk ditarik dalam pembuatan skin flap. Keberhasilan teknik skin flap ditentukan oleh vaskularisasi yang sehat di daerah penempelan (dasar luka). Kulit yang ditempelkan juga harus memiliki vaskularisasi, laju cairan di dalamnya berfungsi dengan baik, serta penempelan harus stabil dan tidak terjadi banyak pergerakan (Erwin, dkk, 2016). 
Pada operasi, kulit donor diposisikan ke area luka terbuka dan dijahit menggunakan benang vicryl 2.0 dengan pola jahitan simple interrupted. Disatukan kulit bagian tengah yaitu bagian abdomen yang menjadi donor dengan jahitan simple interupted. Setelah dilakukan penjahitan, diberikan antibiotik gentamicin berupa salep dan dibalut dengan kasa steril. Perawatan pascaoperasi yaitu luka dibersihkan setiap dua kali sehari dan diberikan antibiotik ceftriaxone dan ketoprofen sebagai analgesik dan sebagai antiinflamasi. Ceftriaxone merupakan antibiotik golongan sefalosporin generasi ke 3. Sefalosporin termasuk golongan betalaktam spektrum luas yang bekerja dengan cara menghambat sintesis dinding sel mikroba. Keunggulan Ceftriaxone meliputi angka resistensi terhadap ceftriaxone yang rendah, efek samping lebih rendah, dan durasi terapi lebih singkat (Abdurachman dan Febrina, 2018).

Faktor yang mempengaruhi kesembuhan luka yaitu: 1) Usia, semakin tua hewan maka akan menurunkan kemampuan penyembuhan jaringan; 2) Infeksi, menyebabkan kerusakan pada jaringan; 3) Hipovolemia, kurangnya volume darah akan mengakibatkan vasokonstriksi dan menurunnya ketersediaan oksigen dan nutrisi untuk penyembuhan luka; 4) Hematoma, hematoma merupakan bekuan darah. Seringkali darah pada luka secara bertahap diabsorbsi oleh tubuh masuk kedalam sirkulasi. Tetapi jika terdapat bekuan yang besar hal tersebut memerlukan waktu untuk dapat diabsorbsi tubuh, sehingga menghambat proses penyembuhan luka; 5) Benda asing, benda asing seperti pasir atau mikroorganisme akan menyebabkan terbentuknya suatu abses sebelum benda tersebut diangkat.; 6) Iskemia, iskemia merupakan suatu keadaan dimana terdapat penurunan suplai darah pada bagian tubuh akibat dari obstruksi dari aliran darah; 7) Diabetes, hambatan terhadap sekresi insulin akan mengakibatkan peningkatan gula darah, nutrisi tidak dapat masuk ke dalam sel; 8) Pengobatan, obatobatan seperti steroid dapat menurunkan mekanisme peradangan normal tubuh terhadap cedera, obat Antikoagulan dapat mengakibatkan perdarahan (Sudimartini, 2016).

Proses penyembuhan dapat dibagi dalam tiga fase menurut Yenti dkk. (2011) yaitu pertama fase inflamasi merupakan reaksi tubuh terhadap luka yang dimulai setelah beberapa menit dan berlangsung selama sekitar tiga hari setelah cedera. Ada dua proses utama yang terjadi selama fase peradangan ini, yaitu hemostatis (mengontrol perdarahan) dan epitelialisasi (membentuk sel-sel epitel pada tempat cedera). Terlalu sedikit inflamasi yang terjadi akan menyebabkan fase inflamasi berlangsung lama dan proses perbaikan menjadi lama. Terlalu banyak inflamasi juga dapat memperpanjang masa penyembuhan karena sel yang tiba pada luka akan bersaing untuk mendapatkan nutrisi yang memadai.Fase proliferatif merupakan fase kedua dalam proses penyembuhan yang memerlukan waktu 3 sampai 24 hari. Kedua, fase regenerasi merupakan fase pengisian luka dengan jaringan granulasi yang baru dan menutup bagian atas luka dengan epitelisasi. Ketiga, fase remodeling merupakan tahap terakhir proses penyembuhan luka, dapat memerlukan waktu lebih dari satu tahun, bergantung pada kedalaman dan luas luka. Jaringan parut kolagen terus melakukan reorganisasi dan akan menguat setelah beberapa bulan. Namun, luka yang telah sembuh biasanya tidak memiliki daya elastisitas yang sama dengan jaringan yang digantikannya.

\section{KESIMPULAN}

Tindakan bedah metode skin flapping dengan rotation flaps dapat digunakan dalam penanganan luka terbuka pada kucing. Penanganan pascaoperasi yang diberikan meliputi pembersihan luka, pemberian antibiotik berupa ceftriaxone, dan pemberian antiinflamasi berupa ketoprofen.

\section{UCAPAN TERIMA KASIH}

Penulis mengucapkan terimakasih kepada Fakultas Kedokteran Hewan UB, 
dosen pembimbing dan Laboratorium Klinik dan Bedah Fakultas Kedokteran Hewan Universitas Brawijaya.

\section{REFERENSI}

Abdurrachman dan Ellin, F. 2018. Evaluasi penggunaan antibiotik pada pasien anak penderita demam tifoid di rumah sakit Al Islam Bandung. Jurnal Farmaka, $16(2)$.

Baroni, A., Buommino, E., Gregorio, V.D., Ruocco, V., Wolf, R. 2012. Structure and function of the epidermis related to barrier properties. Clin. In Dermatol, 30, 257-262.

Erwin dan Deni, N., Gunanti dan Eka, I.P. 2016. Kesembuhan Skin Flap H-Plasty dan Linear Closure untuk Penutupan Luka Area Lateral Thoraks. Jurnal Sains Veteriner, 34(2).

Erwin, Syafruddin, S., Karmil, T., Sugito, T., Daud, R., Roslizawaty, Zainuddin dan Luksmana, R. 2020. Observasi Kesembuhan Distant Skin Flap yang
Dirawat dengan Dry Dressing dan Moist Dressing. Acta Veterinaria Indonesiana, 8(2), 31-36.

Kanitakis, J. 2002. Anatomy, histology and immunohistochemistry of normal human skin. European Journal of Dermatology, 12(4), 390-401.

Sudimartini, L.M. 2016. Penanganan Kasus Hernia Inguinalis pada Anjing Mix Pomeranian. UPT Perpustakaan Udayana, Bali.

Tsuroyya, V.I. dan Adji, D. 2018. Evaluasi Hasil Aplikasi Teknologi Skin Flapping Single Pedicle dan H Plasty untuk Penanganan Luka pada Pasien Kucing. Karya Ilmiah. Universitas Gadjah Mada. Yogyakarta.

Yenti, R., Afrianti, R., dan Afriani, L. 2011. Formulasi krim ekstrak etanol daun kirinyuh (Euphatorium odoratum L.) untuk penyembuhan luka. Majalah kesehatan pharma medika, 3(1), 227230. 